\title{
CHOICE OF MATERIAL FOR MOLDING POROUS CERAMIC DIAPHRAGMS
}

\author{
Yu. I. Komolikov ${ }^{1}$ and I. D. Kashcheev ${ }^{2}$
}

Translated from Novye Ogneupory, No. 12, pp. 35 - 38, December, 2012.

Original article submitted July 6, 2012.

Basic requirements are formulated for starting materials for manufacturing porous ceramic diaphragms, and alumina-containing raw materials of domestic and overseas production are studied. Porous ceramic is manufactured with $35 \%$ open porosity and ultimate strength in compression of $72 \mathrm{MPa}$.

Keywords: alumina, porous ceramic, diaphragm.

Porous ceramic diaphragms exhibit a number of unique properties, and due to this have a broad range of applications. The main advantages of ceramic diaphragms compared with those manufactured from other materials are an increase in structural mechanical strength and stiffness, corrosion and heat resistance, operating property stability with prolonged use, the possibility of object repeated regeneration, and resistance to action of bacteria. Ceramic diaphragms are readily cleaned by calcining, reverse flow of water or other liquid. These properties make it possible to use ceramic filter elements during separation of solutions over a wide $\mathrm{pH}$ range (from 0 to 14), and with high temperature and pressure $(1-10 \mathrm{MPa})$. Ceramic diaphragms are reliable and long last-

1 OOO Keramika, Ekaterinburg, Russia.

2 FGAOU VPO Ural Federal University, Ekaterinburg, Russia. ing in operation $[1,2]$. However, in order to manufacture ceramic materials high-temperature firing is required, during which there is formation of the structure required. The sintering temperature is reduced by introducing sintering additions into a charge or use of special materials in order to obtain a porous structure [3].

During mass production of microporous diaphragms it is interesting to prepare them on the basis of aluminum oxide, as the most widespread and available material. Some of the powders offered on the market have been analyzed in this work.

In selecting aluminum oxide $\mathrm{Al}_{2} \mathrm{O}_{3}$ powder suitable for manufacturing porous diaphragms, one is guided by the following criteria established by experiment.

1. Aluminum oxide should be in the form of corundum.

TABLE 1. Test Powder Properties

\begin{tabular}{lclccccc}
\hline $\begin{array}{c}\text { Alumina } \\
\text { powder }\end{array}$ & $\begin{array}{c}\text { Powder } \\
\text { grade }\end{array}$ & \multicolumn{1}{c}{ Producer } & $\begin{array}{c}\alpha-\mathrm{Al}_{2} \mathrm{O}_{3} \\
\text { content, } \%\end{array}$ & $\begin{array}{c}\text { Specific } \\
\text { surface, } \mathrm{m}^{2} / \mathrm{g}\end{array}$ & $\begin{array}{c}\text { Aggregate } \\
\text { size, } \mu \mathrm{m}\end{array}$ & $\begin{array}{c}\text { Crystallite } \\
\text { size, mm }\end{array}$ & Note \\
\hline 1 & Oksidal & Krasnoyarsk Aluminum Combine & $93-97$ & $4.0 \pm 0.2$ & $\leq 10$ & $<1$ & Unidentified phase content $3-7 \%$ \\
2 & $\mathrm{CTC}-40$ & Almatis (Germany) & $91-92$ & $2.3 \pm 0.11$ & $1-10$ & $<1$ & ${\mathrm{Contains} \mathrm{about} 9 \% \beta-\mathrm{Al}_{2} \mathrm{O}_{3}}$ \\
3 & $\mathrm{GN}$ & Boksitogorsk Aluminum Plant & $94-95$ & $0.6 \pm 0.1$ & $\leq 5$ & $<1$ & Additional phases not determined \\
4 & $\mathrm{G}-00$ & Bogoslovsk Aluminum Combine & $\leq 82$ & $1.9 \pm 0.1$ & $20-180$ & Not det. & \\
5 & $\mathrm{Al}_{2} \mathrm{O}_{3}$ & Siberian Chemical Combine & $90-94$ & $92.0 \pm 2.0$ & $\leq 40$ & - & ${\text { Powder contains } \gamma, \delta, \theta-\mathrm{Al}_{2} \mathrm{O}_{3}}$ \\
6 & $\mathrm{CT}-1200$ & Almatis (Germany) & 98 & 2.9 & $20-150$ & $1-2$ & - \\
7 & $\mathrm{CT}-3000$ & Ditto & 98 & 7.6 & $5-200$ & $0.1-2$ & - \\
8 & $\mathrm{~A}-\mathrm{IAM}$ & Inframat Advanced Materials (USA) & 99.9 & $10 \pm 0.5$ & $\leq 40$ & $0.15-1$ & - \\
\hline
\end{tabular}



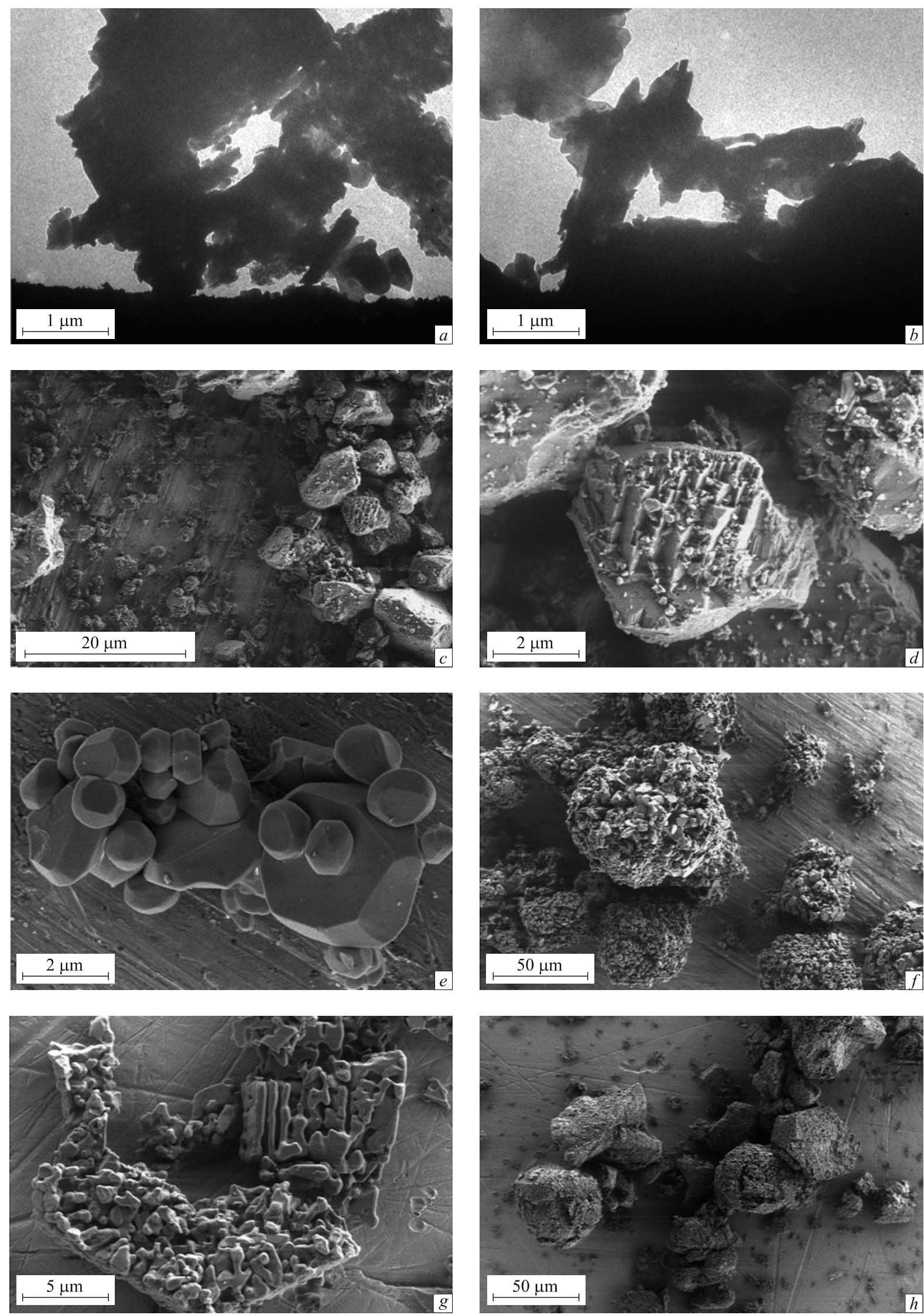

Fig. 1. Alumina powder (see Table 1): $a, b$ ) Oksidal; $c, d$ ) CTC-40; $e, f$ ) GN; $g, h$ ) G-00; $i, j$ ) Siberian Chemical Combine $\mathrm{Al}_{2} \mathrm{O}_{3} ; k, l$ ) CT- $1200 ; m, n) \mathrm{Ct}-300 ; o, p) \mathrm{A}-\mathrm{IAM}$. 

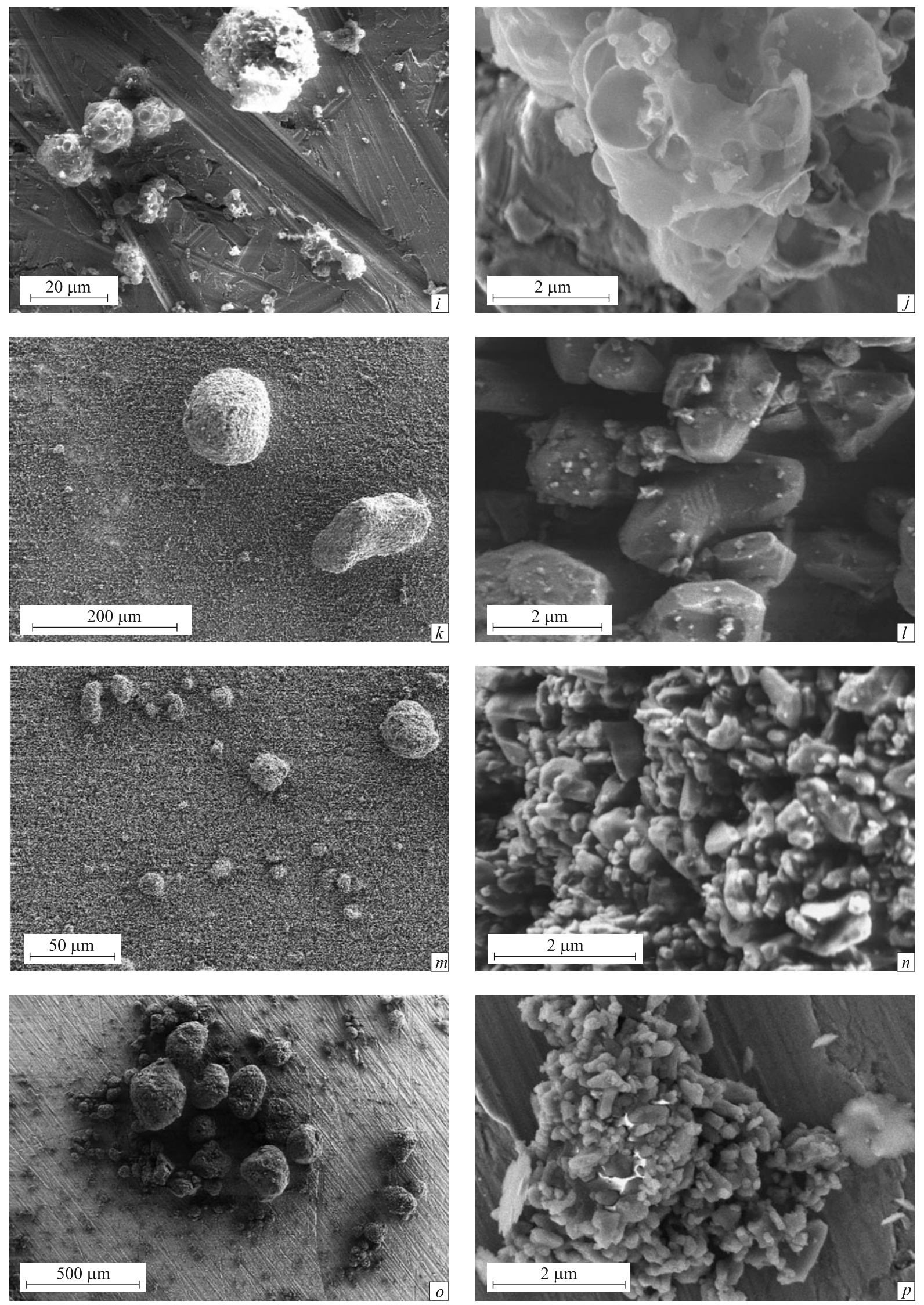

Fig. 1. (Continued) 
TABLE 2. Powder Refinement Conditions and Results

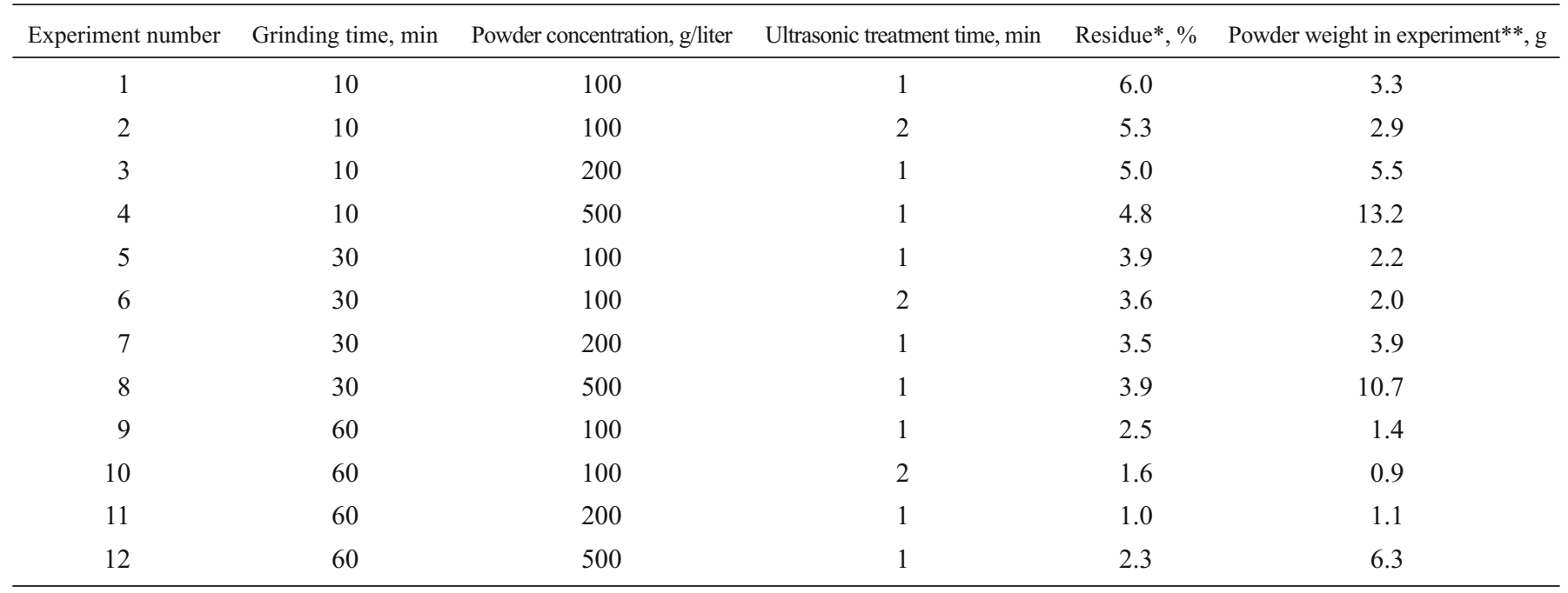

* Of original powder weight.

** Volume of alcohol in experiment $550 \mathrm{ml}$.

2. Aluminum oxide should be weakly aggregated, and be aggregates capable of being broken down with action upon them of ultrasonic vibrations or with short duration grinding.

3. Aluminum oxide particles comprising aggregates should have a monomodal distribution.

4. Aluminum oxide powder should have acceptable cost.

A study of alumina powders from different producers has been performed using contemporary analysis methods. The results obtained are presented in Table 1 and in Fig. 1.

We note that all of the experimental data obtained almost coincide with advertised parameters. However, in advertised materials there is no indication that a powder is aggregated and there are coarse particles within it.

Of all of the test powders further production work has been carried out with alumina grade A-IAM, since it answers to the greatest extent production specifications for a microporous ceramic. The starting

A-IAM powder was ground in a centrifugal ball mill type Pulverisette-6 (Germany), within which the vessel material was manufactured from $\mathrm{Al}_{2} \mathrm{O}_{3}$ and the balls from $\mathrm{ZrO}_{2}$. With dry grinding the whole powder after $10 \mathrm{~min}$ was finely ground and stuck to the mill walls and balls. In order to prevent aggregation and sticking subsequent grinding was performed in isopropyl alcohol. Samples were taken after 10, 30 , and $60 \mathrm{~min}$.

Subsequent powder treatment was carried it by a scheme: ultrasonic treatment of a suspension in a UZD1-0.4/22 disperser for $1-2 \mathrm{~min}$, settling of the suspension for $2 \mathrm{~h}$, and decanting the surface layer. After this particles than $10 \mathrm{~mm}$ remained in the deposit. The weight of deposit was from 6 to $1 \%$ with grinding from 10 to $60 \mathrm{~min}$. Results of experiments are provided in Table 2 . In the decanted liquid there were particles with a size less than $10 \mu \mathrm{m}$, including about $97 \%$ of particles with a size less than $0.5 \mu \mathrm{m}$.

Specimens were prepared by semidry compaction from dried powder in carrying out experiment No. 11 (see Table 2). The temporary binder used during compaction was $5 \%$ solution of polyvinyl alcohol, whose weight fraction was $1 \%$ for dry substance. Drying was performed in an air atmosphere at $1250^{\circ} \mathrm{C}$. The specimens obtained had open porosity of $35 \%$ and ultimate strength in compression of $72 \mathrm{MPa}$.

Thus, the results obtained indicate that it is possible to prepare porous ceramic with high strength during low-temperature sintering and minimum grinding duration from $\mathrm{Al}_{2} \mathrm{O}_{3}$ powder grade A-IAM.

\section{REFERENCES}

1. E. P. Garmash, Yu. N. Kryuchkov, and V. N. Pavlikov, "Ceramic membranes for ultra- and microfiltration," Steklo. Keram., No. 6, $19-22$ (1995).

2. N. M. Bobkova, S. E. Barantseva, and O. S. Zalygina, "Stiff membranes made of glass ceramic material of an alkali-free system," Steklo. Keram., No. 6, 10 - 12 (1997).

3. V. V. Smirnov, "Corundum ceramic with low-temperature sintering," Ogneupory, No. 10, 27 (1994). 